\title{
The Importance of External Audit in Detecting Abnormalities and Fraud in the Financial Statements of Public Enterprises in Kosovo
}

\author{
Hysen ISMAJLI ${ }^{\star}$, Edona PERJUCI ${ }^{\star \star}$, Medina BRAHA ${ }^{\star \star \star}$, Vlora PRENAJ ${ }^{\star \star \star \star}$
}

\begin{tabular}{l}
\hline \multicolumn{1}{c}{ A R T I C L E I N F O } \\
\hline Article history: \\
Accepted February 2019 \\
Available online April 2019 \\
\hline JEL Classification \\
G10, H83 \\
Keywords: \\
Kosovo, External audit, Public \\
enterprises, Financial statements
\end{tabular}

Techniques and tools adopted either in Europe or in the other continents after the recent financial crisis have focused on the urgent need to stabilize financial systems. Since the roles of banks, institutional investors, supervisors, central banks and lately even that of governments and public enterprises have been questioned by the recent eurozone debt crisis, public or private audit is being given more and more attention anywhere in the world.

In this regard, it is important to point out that auditors have an important role and are obliged to adhere to the highest ethical and professional standards. This trust and responsibility given to auditors is an answer to their obligations to the general public to provide a professional opinion on the fair and honest reflection of the financial statements. However, many stakeholders whose decisions are affected by audit reports express doubts and concerns about the relevance and reliability of audit reports, especially after the recent financial crisis and its repercussions (Haddrill, 2010).

Audit quality is characterized by the ability and probability of auditors to detect and report violations, fraud and abnormalities in financial reporting (Deis, Donald, \& Giroux, 1992). Determining factors are more or less the same as in private and public sector audit, so we hope this study will be of wider interest to the public with the very fact that both the International Standards on Auditing (ISAs) in the public sector and the basis of the international standards of public sector auditing ISSAI (International Standards of Supreme Audit Institutions), published by the International Organization of Supreme Audit Institutions (INTOSAI), are very similar with those in the private sector. The only changes appear in the disclosure section.

Independence, professionalism and integrity are among the most important factors influencing public sector audit. This research shows pretty clearly there is room for improvement in functioning of the Kosovo National Audit Office towards developing the quality of reporting and transparency of public enterprises. Data has been obtained from observations, documents, questionnaires, and interviews. Respondents were internal auditors of public enterprises in Kosovo as well as external auditors of the Kosovo National Audit Office. The paper contains a literature review, an overview of public sector (pubic enterprises) audit in Kosovo, the research methodology, analysis of results, and ends with conclusions and recommendations derived from the research work. 


\section{Review of theory and literature}

The public sector consists of a large number of non-profit organizations including central government departments and local councils. The public sector in most cases involves a wide variety of organizations the financial statements of which should be audited by an independent external auditor in order to ensure the community the work was carried out with the right responsibility (Broadbent \& Guthrie, 1992). In the public sector, external audit tends to cover a wider spectrum than that of the private sector. The audit scope in the former includes not only auditing financial records and controlling operations in accordance with regulations, but, at the same time, the audit of acting in accordance with the three Es (economy, efficiency and effectiveness). Audit is an important part of fulfilling public accountability and provides an independent control over how the public funds are collected and spent.

The public sector often operates under a wide spectrum of regulations. For most public-sector audits, the audit object and objectives are influenced by the specific interests and requirements of third-party organizations such as auditing bodies and government-backed departments that have specific regulatory responsibilities.

The way auditors perform their work is influenced by audit standards and other regulatory impacts including:

- Specific legal requirements

- Requirements of audit oversight bodies or supporting departments

- Contractual requirements that contain the terms of engagements

The nature of the regulations affecting public sector bodies varies according to the detailed administrative requirements. Auditors of a public body are expected to take reasonable steps to keep in mind the fulfillment by the audited body of regulations that relate to its activities. In Great Britain, for example, there is an increase in awareness and commitment to the handling of fraud and anomalies detected by audits. The National Anti-Fraud Audit Initiative (NFI) was established by a decision by the UK's prime minister in 1998 with the aim of disclosing fraud in public sector. NFI is a welcomed development in this regard, using technology to identify major frauds and their amounts, then using the lessons learned to address the risks. This initiative uses advanced data coordination techniques to address a wide range of fraud risks faced by the public sector. Meetings are provided as references to participating organizations in the friendly use of the application to allow the prioritization of matches and the propagation of investigators without compromising privacy of data.

A major problem in managing funds and resources in the public sector is the possibility of misuse, fraud and corruption. The World Bank's report (Anderson \& Gray, 2006) underlines factor in fighting corruption:

- Anticorruption efforts are successful when rules and regulations are simplified, interactions between firms and public officials are limited and private sector bills are reduced. Just as countries open up to global integration, corruption tends to fall, but advanced countries need to be vigilant about this problem.

The traditional task of Supreme Audit Institutions in each country is to audit the legality and regularity of financial management and accounting (Baber, 1983). In addition to this type of audit and its importance, there is also a similar type of audit that is performance audit which is oriented towards performance control, focusing on economy, efficiency, and effectiveness of public administration. Performance audit covers not only specific financial operations, but the entire range of government activities, including both organizational and administrative systems. When talking about auditing in the public sector, it is undoubtedly very important to present the division of audit types in the public sector and the distinction between financial audit and performance audit.

\section{Financial audit in public sector}

Scholars provide a variety of definitions with regard to financial audit (including compliance audit) in public sector.

- Review financial statements of auditors, accounts, operations and other financial information if they are in compliance with laws and regulations and if they present fair and honest (Gong, 2009). While Russell (2000) added that a financial audit involves examining product and service specifications in order to ascertain whether auditors are in compliance with specific requirements or standards.

- Examining public sector financial reports to obtain information, explanations and to provide justifications from the audited in providing transparency and accountability in the management of finance and public assets (Mulgan, 2008). Moreover, in the context of the public sector, Houghton and Jubb (2003) added that the financial audit output is an opinion on transparency and accountability by the audited institutions. Auditor's opinion is valuable information to reflect the economic and financial conditions of a country, thus reducing the risk for the general public and capital markets. 
- Examining financial reports and their compliance with laws, regulations, including auditing standards, to support government anti-corruption programs (Nicoll, 2005).

- Verifying the financial statements by referring to the variety of evidence such as bills, minutes of board meetings, contract notes, cost and market values (Sikka, Filling, \& Liew, 2009)

\section{Performance audit in public sector}

Scholars provide a variety of definitions with regard to performance audit in the public sector.

- Assessing the performance of public sector management, providing better public services and reducing public costs and expenditures or examining the effectiveness of programs or projects each time considering the effectiveness and value of money (Broadbent \& Guthrie, 1992).

- Provide recommendations for better public administration performance and government stimulation to deliver better goods and services to the public, and use resources and public resources efficiently and effectively (Houghton \& Jubb, 2003).

- Assessing the management and operational performance of the projects, considering three E-s to achieve the administrative objectives of the new public management (Y.Andy, 2002).

Above definitions represent three key points that performance audit evaluates at public institutions: (1) their efficiency in the use of money and other public funds; (2) their effectiveness in running programs and projects; and (3) their ability to develop the economy by using resources more productively and by implementing and following up constructive audit recommendations for increased performance and service delivery in the public sector.

While performance audit has more to do with the future, long-term strategic orientation makes it relevant since it does not only evaluate and examine outputs and outcomes of a particular program/process, but also its expected impact and benefits. Therefore, we can say that recommendations from the performance audit can be used to evaluate and monitor specific programs and processes that are implemented in the public sector.

\section{Research methodology}

This research was designed using primary and secondary sources of data and was carried out according to statistical analysis methods using the average algebraic size method and absolute variation indicators (Nuhiu, 1995). Secondary data includes international auditing standards for the public sector, Public Enterprises reports, Policy and Monitoring Unit of Public Enterprise (PMUPE) reports, and its implementation as well as audit reports of public enterprises published by the KNAO.

Primary data includes responses from questionnaires and interviews conducted with the leaders and internal auditors of public enterprises in Kosovo as well as with auditors KNAO who had been involved in auditing public enterprises. Two different questionnaires have been prepared, one being dedicated to public enterprises and the other to external auditors. This analysis of data includes information on whether audit recommendations are addressed by public enterprises and whether disciplinary or judicial proceedings against public enterprise managers have been initiated based on those audit findings in public enterprises. Furthermore, the impact of audit quality in detecting fraud and anomalies in the financial statements of public enterprises is tested. Respondents were asked to express the level of compliance with some statements/affirmations made regarding the audit of public enterprises and the audit quality in these enterprises. Respondents were asked to rank their responses using a Likert scale of 1 to 5 (where 5 represent full compliance). The weighted average is divided by 5 (maximum level of compliance) and multiplied by 100 to get the percentage that indicates how close to full reconciliation is the average affirmation. The scale is calculated using:

$$
s=(\Sigma w i x i / n) * 100 / 5
$$

where:

$\mathrm{wi}=\mathrm{xi} ; \mathrm{s}$ is the degree of compliance with the statement

$\mathrm{w}$ is the weight of weighting

$\mathrm{x}$ is the rank given by each respondent, and

$\mathrm{i}=1,2, \ldots ., \mathrm{n}$ represents the respondents.

\section{Objectives of the study}

Based on literature research, primary and secondary data analysis, we try to achieve the main objectives of this study. Later, based on these we are providing recommendations on the improvement of reporting, financial management, transparency, and accountability within public enterprises.

$>$ The quality of external audit affects the detection of fraud and anomalies in the financial statements of public enterprises in Kosovo.

> For external auditors, there is a direct link between errors and frauds and financial reporting.

$>$ External auditors consider the potential risk of error and fraud as being high 


\section{Characteristics of respondents and research results}

Table 1. Demographic distribution of respondents

\begin{tabular}{|l|l|r|}
\hline Variables & Categories & Frequency in \% \\
\hline \multirow{3}{*}{ Education level } & Bachelor & $28 \%$ \\
\cline { 2 - 3 } & Master & $68 \%$ \\
\cline { 2 - 3 } & PhD/Doctorate & $4 \%$ \\
\hline \multirow{3}{*}{ Certification level } & Accounting technician & $36 \%$ \\
\cline { 2 - 3 } & Certified accountant & $48 \%$ \\
\cline { 2 - 3 } & Licensed auditor & $16 \%$ \\
\hline \multirow{3}{*}{ Audit experience } & Less than 5 years & $68 \%$ \\
\cline { 2 - 3 } & 5 to 10 years & $24 \%$ \\
\cline { 2 - 3 } & 10 to 15 years & $0.0 \%$ \\
\cline { 2 - 3 } & More than 15 years & \\
\hline
\end{tabular}

\section{Assessment of potential risk of error and fraud}

The results on assessing possible risk of errors and frauds are presented in Table 2 which corresponds with the first section of the questionnaire. Statements regarding that kind of risk include: auditor skepticism affects delivery of final opinion on financial statements; division of labor and tasks reduces possibility of fraud; conflicts of interest in assigning duties increases likelihood for fraud; and functioning of internal audit influences application of independent tests by external auditor. The arithmetic average of respondents' responses in this category reaches 4 points which consists with the alternative Agree, while the standard deviation is results to be 0.68 .

Table 2. Assessment of potential risk of error and fraud

\begin{tabular}{|l|r|r|}
\hline \multicolumn{1}{|c|}{ Section 1 of the questionnaire } & \multicolumn{1}{|c|}{$\begin{array}{c}\text { Arithmetic } \\
\text { mean }\end{array}$} & \multicolumn{1}{|c|}{$\begin{array}{c}\text { Standard } \\
\text { deviation }\end{array}$} \\
\hline $\begin{array}{l}\text { Auditor skepticism affects delivery of final opinion on financial } \\
\text { statements }\end{array}$ & 3.64 & 0.67 \\
\hline Division of labor and tasks reduces possibility of fraud & 4.18 & 0.60 \\
\hline Conflicts of interest in assigning duties increases likelihood for fraud & 4.45 & 0.52 \\
\hline $\begin{array}{l}\text { Functioning of internal audit influences application of independent tests } \\
\text { by external auditor }\end{array}$ & 3.73 & 0.90 \\
\hline Total & 4 & 0.68 \\
\hline
\end{tabular}

\section{Detection of error and fraud}

Table 3 shows the results related to the second part of the questionnaire which describes the detection of error and fraud. This section includes the following statements: mistakes are intentional acts; manipulations, forgeries, information distortions or document changes are frauds; misappropriation of assets is fraud; misapplication of accounting principles is fraud and error; bypass or misinterpretation of facts is fraud; and mistakes in calculating or notetaking are frauds. In this category of answers the overall arithmetic average is 3.76 which is closer to the alternative agree, while the standard deviation is 0.94 .

Table 3. Detection of error and fraud

\begin{tabular}{|l|r|r|}
\hline \multicolumn{1}{|c|}{ Section 2 of the questionnaire } & $\begin{array}{c}\text { Arithmetic } \\
\text { mean }\end{array}$ & $\begin{array}{c}\text { Standard } \\
\text { deviation }\end{array}$ \\
\hline Mistakes are intentional acts & 2.73 & 1.27 \\
\hline Forgeries, information distortions or document changes are frauds & 4.91 & 0.30 \\
\hline Misappropriation of assets is fraud & 4.36 & 0.67 \\
\hline Misapplication of accounting principles is fraud and error & 3.64 & 1.03 \\
\hline Bypass or misinterpretation of facts is fraud & 3.82 & 1.17 \\
\hline Mistakes in calculating or notetaking are frauds & 3.09 & 1.22 \\
\hline Total & 3.76 & 0.94 \\
\hline
\end{tabular}

\section{Impact of Errors and Fraud in Financial Reporting}

Table 4 contains the results that relate to the third part of the questionnaire, describing the impact of errors and frauds in the financial report. Statements representing this section are: errors and fraud affect fair 
financial reporting; external audit affects the discovery of anomalies and fraud in financial statements of public enterprises; recommendations from external audit reports are applied by public enterprise in their reporting; vast majority of fraud and error reporting is done by clients or other parties outside the institution; reporting error and fraud should be based on sufficient evidence that they have been committed; and auditors the team of discovering and reporting error and fraud should have good forensic analysis skills. In this category of answers the overall arithmetic average is 3.98 corresponding to the alternative Agree, while the standard deviation is 0.71 .

Table 4. Impact of errors and fraud in financial reporting

\begin{tabular}{|l|r|r|}
\hline \multicolumn{1}{|c|}{ Section $\mathbf{3}$ of the questionnaire } & \multicolumn{1}{|c|}{$\begin{array}{c}\text { Arithmetic } \\
\text { mean }\end{array}$} & $\begin{array}{c}\text { Standard } \\
\text { deviation }\end{array}$ \\
\hline Errors and fraud affect fair financial reporting. & 4.36 & 0.67 \\
\hline $\begin{array}{l}\text { External audit affects the discovery of anomalies and fraud in financial } \\
\text { statements of public enterprises }\end{array}$ & 4.36 & 0.67 \\
\hline $\begin{array}{l}\text { Recommendations from external audit reports are applied by public } \\
\text { enterprise in their reporting. }\end{array}$ & 3.82 \\
\hline $\begin{array}{l}\text { Vast majority of fraud and error reporting is done by clients or other } \\
\text { parties outside the institution. }\end{array}$ & 3.09 \\
\hline $\begin{array}{l}\text { Reporting error and fraud should be based on sufficient evidence that } \\
\text { they have been committed. }\end{array}$ & 0.75 \\
\hline $\begin{array}{l}\text { Auditors the team of discovering and reporting error and fraud should } \\
\text { have good forensic analysis skills. }\end{array}$ & 4.36 & 0.94 \\
\hline Total & 3.91 & 0.50 \\
\hline
\end{tabular}

Table 5. Respondent responses

\begin{tabular}{|c|c|c|c|c|c|}
\hline Respondents & Completely disagree & Disagree & Neutral & Agree & Completely agree \\
\hline Mean & 2 & 18 & 27 & 77 & 52 \\
\hline
\end{tabular}

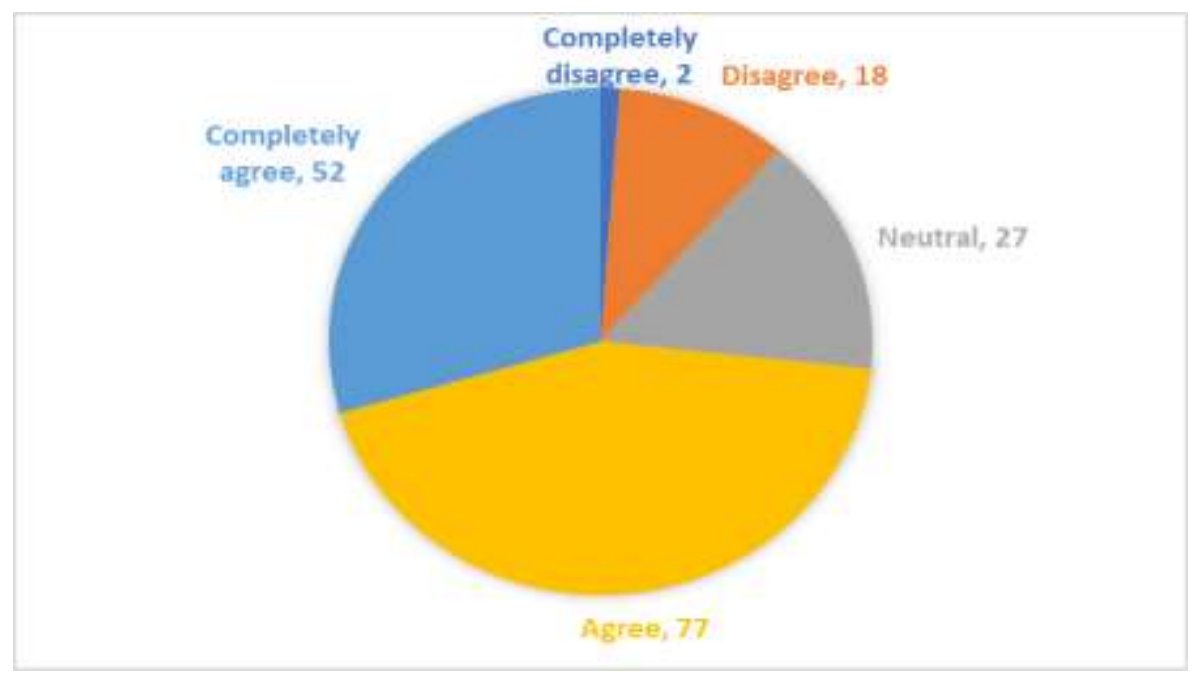

Figure 1. Mean of respondent responses

\section{Research results}

In this study, research results were reported using the algebraic mean method and the absolute variation indicators (Nuhiu, 1995), by means of SUMIF and COUNTIF tools. The objective of this work is to empirically test whether the abovementioned factors affect the discovery of anomalies and fraud in the financial statements of public enterprises in Kosovo.

Based on findings presented in Table 2, the claim that external auditors consider the potential risk of errors and fraud as being high resulted in an overall average of 4 and a standard deviation of 0.68 . As such, the claim seems to receive significant support. In addition, the claim that external auditors have aversive attitudes towards frauds and errors results in a mean of 3.76 and a standard deviation of 0.94 . While for the claim that for external auditors there is a negative ratio between errors and frauds and financial reporting, 
the findings suggest an overall mean of 3.98 and a standard deviation of 0.71 which show that mistakes and fraud affect financial reporting.

According to this research and the achievement of the main objectives we can conclude that the factors accepted by respondents as valid in detecting anomalies and fraud within the financial statements of public enterprises seem to be: assessment of possible risk of errors and fraud; for external auditors there exists a direct link between error and fraud and financial reporting; and quality of external audit positively affects detection of fraud and anomalies within financial statements.

\section{Conclusions and recommendations}

The key issue considered important is the independence and objectivity in auditing public enterprises, which is regarded as a guard of constitutional and democratic governments. But its economic, efficient and effective organization remains a constant challenge at this time of social and economic change and current political circumstances. There is no final plan for success, as final success in itself has different meanings in different countries and different circumstances.

Regardless of whether the audit report is about providing sight on a fair and honest presentation of financial situation or on determining performance audit, auditing the public sector requires the exercise of professional judgment. Not every auditor examining the same situation and facts comes to the same conclusions. The audit concerns the application of principles and not rules (Bourn, 2007). Here is a spectrum with a conclusion, the auditor can find "prima facie" evidence, where according to the relevant law fraud is committed, and most of the auditors would agree. But, on the other side of the spectrum, where complex economic and social programs are reviewed, different assessments and interpretations become apparent.

The main purpose of this paper has been to establish whether external audit affects the discovery of anomalies and fraud in the public financial statements in Kosovo. The findings of this paper suggest that external auditors consider the potential risk of errors and fraud as being high, that they have aversive attitudes against errors and fraud, and that for them there exists a negative relationship between errors and fraud and financial reporting.

Based on the investigation, lack of implementation of public enterprises audit findings has been found, hence the below is recommended:

- Necessary measures from the Public Enterprise Unit should be taken towards management of those enterprises in cases of failing to rightly, correctly, and timely implementing the KNAO recommendations.

- Disciplinary actions should be initiated and taken wherever audit reports reveal fraud in the financial statements of public enterprises.

- Continues assurance should be provided to the legislative body, government and general public in that public services are open for full inspection by independent external auditors and that the responsibility of public servants can be demonstrated.

- External auditing in the public sector should be seen as a profession that adds value and so contributes to increasing the efficiency of public services and which will increase the public's trust in financial reporting and financial management of the public sector.

- External audit should be independent from government and legislative body and it should be carried out by professionals who have the appropriate professional and ethical competences and come from a wide range of experiences. This is crucial in order for the public sector audit to be completed in a qualitative manner what is most required from auditors of this sector. On the contrary, i.e. if public sector external auditors cannot write and speak freely, if their rights are limited, if the government unjustly limits staff size and reward then the above qualitative completion will not be achieved.

\section{References}

1. Anderson, J., \& Gray, C. (2006). Anti-Corruption in Transition: Who is succeeding and why? World Bank.

2. Baber, W. R. (1983). Toward understanding the role of auditing in the public sector. Journal of Accounting and Economics, pp.213 - 227.

3. Bourn, S. J. (2007). Public sector auditing: is it value for money? Pp. 356.

4. Broadbent, J., \& Guthrie, J. (1992). Changes in the public sector: A review of recent "alternative" accounting research. Accounting, Auditing \& Accountability Journal.

5. Deis, J., Donald, R., \& Giroux, G. (1992). Determinants of audit quality in the public sector. Accounting Review, pp.462 479.

6. Gliem, Joseph A dhe Rosemary R. Gliem. "Calculation of Model Likert" Midweat Research -to - Practice Conference in Adult, Continuing and Community Education. The Ohio State University Columbus, $\mathrm{OH} 2003$

7. Gong, T. (2009). Institutional learning and adaptation: developing state audit capacity in China. Public Administration and Development, pp: $89-166$.

8. Haddrill, S. (2010). Should statutory audit be dropped and assurance needs left to the market? ICAS Aileen Beattie memorial event.

9. Houghton, K. A., \& Jubb, C. A. (2003). The Market for Financial Report Audits: Regulation of and Competition for Auditor Independence. Law \& Policy, vol.25, Issue 3, pp.229 - 321.

10. INTOSAI. International Organization of Supreme Audit Institutions. 
11. Mulgan, R. (2008). How much responsiveness is too much or too little? The Australian Journal of Public Administration, pp.345 - 356 .

12. Nicoll, P. (2005). Audit in Democracy. Ashgate Publishing Ltd England.

13. Nuhiu, R. (1995). Bazat e Statistikes. Prishtine.

14. Power, M. (1997). The audit society. Rituals of verifications.

15. Russell, J. P. (2000). The Quality Audit Handbook: principles, implementation, and use, 2nd edition. American Society for Quality (ASQ) Press, Milwaukee, Wis.

16. Sikka, P., Filling, S., \& Liew, P. (2009). The audit crunch: reforming auditing. Managerial Auditing Journal, pp:135 - 155.

17. Y.Andy. (2002). Public accountability and performance auditing in government. International Journal of Auditing, pp. $109-118$. 